\title{
Local Wisdoms: New Media of Teaching Speaking in Showing Local Identity Protection and Characters (Classroom Ideas)
}

\author{
Dwi Rosita Sari \\ Universitas PGRI Madiun \\ Madiun, East Java, Indonesia \\ rositasari_dwi@yahoo.com
}

\begin{abstract}
Local wisdoms show certain group of people's way of life. It is closely related to the way how a group of people in certain area built their characters and identity. The concept of local wisdom in environmental was described by [1] with the term means collection of knowledge, practices, and beliefs that evolved through adaptive process (adjusment) passed from generation to generation through culture, associated to the relationship between living beings (including the humans) with the surounding environments. In this article, the author will disscuss the implementation of the philosophy of Madiun's local wisdoms in teaching speaking for Vocational School students which show the students' local identity and build good characters. Madiun's local wisdoms will be an interesting media to teach speaking as part of Indonesia's and Asia's local wisdoms. This idea is aimed to: (1) show the implementation of the philosophy of Madiun's Local Wisdom in Teaching Speaking, (2) To describe the implementation of the philosophy of Madiun's Local Wisdom for Vocational School Students increase students' speaking ability. The research was conducted in SMKN 1 Madiun. The population will be the students of SMKN 1 Madiun. The research belongs to Research and Development (R\&D). Next, implementing local wisdoms in teaching as a means of local identity protection.
\end{abstract}

Keyword - Local Wisdom, Local Identity, Teaching Speaking, Vocational School Students

\section{INTRODUCTION}

Speak fluently is the indicator that someone can master English well. In fact, speaking thought as difficult skill to be mastered since teachers use conventional media in teaching.

Based on the previous research done by Dwi Rosita Sari and Rosita Ambarwati at 2015 with the title "Implementasi Falsafah Setia Hati Terate Pada Pembelajaran Speaking (Strategi Pengembangan Karakter
Siswa Berbasis Local Wisdom)" shows that a large part of them feel proud of their city and SH Terate Madiun which popular in Indonesia as local wisdom. Having high interest and using the local wisdom as speaking topic, encourage them to speak English fluently.

\section{DISCUSSION}

\section{A. Local Wisdoms}

Every district has local wisdoms. The Existence of the Stories in every area there are already documented and published and some are still scattered and published only orally. This also happen to Madiun's local wisdoms. They are documented orally. There are more than five local wisdoms which exist in Madiun. The local wisdoms are:

\section{Raden Ayu Retno Dumilah}

Raden Ayu Retno Djumilah is a smart and swift woman. She is the daughter of Pangeran Timoer. She was appointed as the second Purbaya regent in 1586 . She was a woman leader who was really regarded. She did not only get an overflow of leadership as Purbaya regent but also acted as war commander from Purbaya regency in warfare opposing Mataram Kingdom. The large number of Mataram Kingdom formation really made difficulties for Purbaya regency which only had a few number of formations. Retno Dumilah thought wisely, if they continued, the war would only cause the death and hostility that would never end. That wise consideration was finally manifested in a compromise between the two sides. Finally, Retno Djumilah, a smart and swift woman leader, married with the King of Mataram and became an empress. Marking the end of war, on November 16 1590, the name of Purbaya regency was replaced to be Madiun.

\section{Kresek Monument}

Kresek monument was built on the land measuring 2 ha in the middle of the protected forest teak tour. It was the 
Pillar Monument of the Struggle for Indonesian nation especially Madiun against the PKI ferocity (the Party of Indonesian Communists) on 1948. It is located about $8 \mathrm{~km}$ from Madiun city to the east side, precise in Kresek village, Wungu district. This monument was built with the spirit of Madiun people heroism opposed the ferocity of PKI. The Pillar of history was the bitter memory that not forgotten and ought to be recalled by the younger generation of the nation goal in fighting for Pancasila and UUD 1945.

\section{Dongkrek}

Dongkrek is a blend of music and original dance movement from Caruban, Madiun. This art implies the message that every bad intent will eventually be defeated by goodness and righteousness. The composition of one-piece fragmentation players of spirits consists of gigantic demon troops, an old man, and two women. This woman symbolizes the condition of the weak people because besieged by the gigantic demon. Before the gigantic demon troops managed to kill the women, a powerful old man appeared to drive out the spirits to go away. After that, battle was quite fierce between the gigantic demon troops with the old man, who won by the old man. The lost gigantic demon troops were finally obedient and out of the Village.

\section{Setia Hati Terate}

In 1903, Ki Ageng Soero Dwiryo laid the foundation for Pencak Silat Setia Hati in Kampoeng Tambak Gringsing, Surabaya. In 1917, he moved to Madiun to build and establish "Silat" Brotherhood called Persaudaraan Setia Hati in Winongo village, Madiun. Persaudaraan Setia Hati Terate (PSHT) is a muscle art college family aims for teaching and creating a virtuous person who knows what is right and wrong, catious to the God, teaches loyalty to the people, giving priority to brotherhood among members and it is shaped in an Organization that is Faithful Brotherhood fraternal. PSHT is not a sport of fighting but the art of battle. A fighting sport is a struggle with another. An art of battle is a struggle with oneself. The philosophy of SH Terate have become the Basic Principles of Setia Hati Terate, to achieve a balance of physical and spiritual. PSHT was founded on five basic principles, those are: Brotherhood, Sport, Self, Cultural Art, and Spiritual development.

\section{Local foods}

\section{Pecel}

Pecel is a traditional Javanese salad. The origin of pecel is from Madiun, East Java. It consists of mixed vegetables in a peanut sauce dressing.

\section{Brem}

Brem is the traditiona fermented food or fermented beveragel from Madiun. This kind of food is believed by Indonesian consumer to be important for stimulating the blood system. It is also reported to prevent dermatitis, probably due to the presence of significant amounts of B vitamins produced by the microorganisms.

\section{INKA}

PT Industri Kereta Api (Persero) abbreviated as INKA, is a government-owned corporation which was formed on 19 August 1981 as the successor of Balai Yasa Lokomotif Uap owned by PT Kereta Api Indonesia in Madiun. The business activity of PT Industri Kereta Api Indonesia is growing from basic product to the higher value added product and services in railway and transportation business. PT. INKA has been producing a variety of locomotive, train, and car. Many of them are made in cooperation, there is also a body of a car and they were over. Some products even have been exported to foreign countries. With stiff competition between rail and air transportation in recent years, PT Inka is facing an increasingly tough domestic market.

\section{Madiun's Batik}

Batik Nusantara keeps inspiring society to create and find the new innovation of Batik design. It includes Batik Pecelan, Batik Seger Arum, and Batik Madu Mongso from Madiun. Batik Pecelan is inspirited from the variety of Nasi Pecel vegetables, the traditional food from Madiun. Pecel is an inspiration to create the unique and interesting creativities. Batik pecel is created by Murni in 2011. The motif of it is from all of the material used to make Pecel, such as long beans, cassava leaves, turi flowers, peanuts, chili, and others. She also involves some societies to increase their creativity and learn to be autonomous. Batik Seger arum is inspirited from Nambangan Madiun orange which at present has difficulty to be preserved through agriculture because of the narrowness of existing agricultural land and the lack of interest of the society to cultivate it. In order to be known, it is presented through the art of batik. Batik Madu Mongso is inspirited from Madiun's local food that is Madumongso. This food is made from glutinous tape fermented with the help of yeast, just like when we make tempe or tape. The color is black. It is wrapped in colorful paper like candy. It tastes very sweet, but it's the sweetness that makes Madumongso loved by people.

\section{Keris Tundhung Madhiun}

Madiun is an area pioneered by Ki Panembahan Ronggo Jumeno or commonly called Ki Ageng Ronggo. He has a very powerful keris named keris Tundhung Medhiun which is always wrapped in jasmine rinonce flowers by spreading fragrant scent so that the keris will always have a high authority. Thus, jasmine and keris will always coexist which will bring Madiun City to be fragrant. This kris is made by Empu Umyang. It named 
Keris Tundhung Madhiun because the dagger was made when he was expelled (ditundhung) from Demak and when the dagger was made, he saw a ghost (memedi) that was swinging then called Tundung Medhiun.

\section{Pangeran Timoer}

Pangeran Timoer who was appointed to be Purabaya Regent on July 18, 1568 opened and colored the Early History of Madiun Regency, as the first Regent of Madiun with tenure between 1568 and 1586. Several years after being appointed as Purabaya Regent, Pangeran Timoer implemented the idea of moving the Central Government from the North to the South, now in Kuncen Village. The transfer of the Central Government was done for a number of reasons. Firstly, he wanted to have a new place of residence as a sign of the start of his power as a Purabaya Regent. Secondly, the movement of the place was also based on the assumption that the old place was not the center of government. But only as a place of "supervision". The war between Pajang and Mataram which ended with the collapse of Pajang around 1586 caused the breakup of formalities between Purabaya and Pajang. The name of of Pengeran Timoer is known as Pangeran Timoer stadium in Caruban, Madiun.

\section{B. Local Characters and Identity}

Every Madiun's local wisdom represents specific characters. The characters which raise up are:

1. The characters of Raden Ayu Retno Dumilah are persistant, intrepid, smart, and wise.

2. The characters of Kresek Heroes are brave, responsible, high minded/ intellect, dare to die, persistent, sacrifice.

3. The Dongkrek are divided into three characters. The old man who is wise and strong, the female dancer is weak, and the gigantic demon troops are cruel and arrogant.

4. Setia Hati Terate's characters are honest, religious, open minded, respect, smart, tolerant, responsible, brotherhood, and grateful.

5. The characters of Local foods like pecel, madumongso and brem that raise up are creative, inspiring, unique, and interesting.
6. The characters of INKA's staffs are creative, high integrity, innovative, professional, good quality source

7. The characters of Keris Tundung Madiun are high competence, calm and unarrogant.

8. The characters of the inventor of Madiun's batik are creative, inspiring, unique, and creative.

9. The characters of Pangeran Timoer are persistent, religious, and strong stand.

\section{Teaching Speaking through Local Wisdom}

Since the perspective on speaking still exist in students' mindset that speaking is difficult skill. The learning process was still monotonous. Due to this condition, teachers need new model of teaching which relate local wisdom in teaching speaking in order to make the process more interesting. The process of teaching speaking will involve the local wisdoms as the topic of speaking activities.

\section{CONCLUSION}

Learning of speaking should be strived to be an interesting learning so that learning objectives can be achieved. The new model should be created to solve the problem by involving local wisdoms in teaching speaking.

\section{REFERENCES}

[1] Berkes, F. 1993. Application of ecological economics to development: The institutional dimension. Proceedings of a Workshop. IREE/CIDA, Ottawa, pp. 61-71

[2] Berkes, F. 1993. Traditional ecological knowledge in perspective. In: Traditional Ecological Knowledge: Concepts and Cases. (J.T. Inglis, ed.). Canadian Museum of Nature/International Development Research Centre, Ottawa, pp.1-9.

[3] Dongsong, Z. (2005). Interactive Multimedia_based ELearning: A Study of Effectiveness. The American Journal of Distance Education. New York: Lawrence Erlbaum Association, Inc.

[4] Nunan, D. (1989). Designing Tasks for the Communicative Classroom.Cambridge: Cambridge University Press. 